JURNAL AL BAYAN: JURNAL JURUSAN PENDIDIKAN BAHASA ARAB

p-ISSN 2086-9282 | e-ISSN 2549-1229

\title{
The Implementation of Eclectic Methods in Arabic Learning Based on All in One System Approach
}

\author{
Zulfa Amalia Wahidah ${ }^{1}$, Umi Baroroh ${ }^{2}$, Rasheed Mahmoud-Mukadam ${ }^{3}$ \\ ${ }^{1}$ Arabic Education Study Program Universitas Islam Negeri Sunan Kalijaga Yogyakarta, Indonesia \\ ${ }^{2}$ Arabic Education Study Program Universitas Islam Negeri Sunan Kalijaga Yogyakarta, Indonesia \\ ${ }^{3}$ Arabic Study Program University of Ilorin, Nigeria
}

\begin{abstract}
Article History:
Received : October 04, 2020

Revised : November 13, 2020

Accepted : December 15, 2020

Published : June 01, 2021
\end{abstract}

\section{Keywords:}

Eclectic Method; Fun Learning; Integrated Approach; Language Skills

*Correspondence Address: zulfaa32@gmail.com

\begin{abstract}
Each method has different function and characteristic. One method is not enough to achieve four language skills in Arabic language learning. We need a method that is able to accommodate the weaknesses of the previous method. This research aimed to examine the implementation of eclectic method based on all in one system approach. This method integrates the various methods in language teaching and achieves four language skills. This research provided a new model to implementation the methods, specifically eclectic method and their connection with Arabic language skills. The method used in this research was qualitative method based on text analysis. The data research was collected from sources of books, journal articles, or matters relating to the topic of this study. The result of this research was the use of an eclectic method based on all in one system approach (integrated approach) which can facilitate Arabic language teaching. A language teacher needs to consider this method for students. This research also examined the various aspects and how they could be useful for teacher in Arabic language classroom. The study provided further support for the use of eclectic method for student in mastering four Arabic language skills.
\end{abstract}

\section{Introduction}

The emergence of an integrated teaching system (All in One System) is a response to the failure from separated teaching system. The weakness of the separated teaching system is four language skills teaching carried out separately and deeply. As a result of this separation, the students are not able to be balanced in mastering the four language skills which causes inequality in the comprehension of the language. They might master several aspects of language skills, but not comprehensive ${ }^{1}$. According to Roviin $^{2}$, separated method is not suitable with the principles of language, both in terms of

\footnotetext{
${ }^{1}$ Ahmad Izzan, Metodologi Pembelajaran Bahasa Arab (Bandung: Humaniora, 2004), 29.

${ }^{2}$ Roviin, "Pengembangan Kurikulum Bahasa Arab di Madrasah (Analisis Pendekatan, Model dan Prosedur)," Jurnal Tarling, 1, 2 (2018): 12.
} 
application learning and function. The separation of teaching speaking, writing, listening and reading skills is one of the causes the quality stagnancy of Arabic learning in Indonesia.

Considering to this problem, All in One System approach becomes something important to be discussed. All in One System approach is a theory that views the effective language learning of four language skills if it is done integrally which there is no separation in teaching language skills. According to Makruf (2016) ${ }^{3}$, learning Arabic will be effective if an integrated approach is applied. Through this approach, the language skills such as istima, 'kalam, qiroah and kitabah are automatically learned together in one learning theme. Amal Abed Rabbo ${ }^{4}$ indicated that the use of All in One system approach is very effective in terms of the achievement of student values in learning. Here, an eclectic method is needed ${ }^{5}$. The method is an important factor for achieving four language skills ${ }^{6}$. From the previous studies, a discussion about the appropriate and effective method in an integrative approach was not found yet.

Language teaching requires methods that are in accordance with the principles of All in One System. Brown (2000) explained that the use of All in One method is not effective and efficient in language learning because there are four language skills that must be mastered by students ${ }^{7}$. Language is fully integrated and Arabic skills teaching learning also needs comprehensive teaching method ${ }^{8}$. The characteristics of this method are suitable for teaching four language skills. This method combines the advantages of a variety of different methods. This method is systematically and logically combined to meet the needs of learners ${ }^{9}$.

In this study, researchers conducted a study of eclectic methods in learning Arabic. In previous research, the old model of implementing eclectic method in Arabic skills was still used. Hence, this research aims to provide a new model in the

\footnotetext{
${ }^{3}$ Imam Makruf, "Manajemen Integrasi Pembelajaran Bahasa Arab di Madrasah Berbasis Pondok Pesantren," Cendekia: Journal of Education and Society 14, no. 2 (13 Desember 2016): 265.

4 Ahmad Abu 'Iwadh, Pendekatan Pendekatan dalam Pembelajaran Bahasa Arab (Makkah al Mukarramah, 2000), 132.

${ }^{5}$ H.D Brown, Principles of language learning and teaching (New York: Longman, 2000), 93.

${ }^{6}$ Aziz Fahrurrozi, "Pembelajaran Bahasa Arab : Problematika Dan Solusinya," ARABIYAT: Jurnal Pendidikan Bahasa Arab dan Kebahasaaraban 1, no. 2 (28 Desember 2014): 161-80.

7 Anwar Abd Rahman, "Pengajaran Bahasa Arab Dengan Metode Eklektik," Jurnal Adabiyah 11 (2011): 10 .

${ }^{8}$ Umi Hijriyah Hijriyah, "Pendekatan-Pendekatan Dalam Belajar Bahasa," Jurnal Al Bayan: Jurnal Jurusan Pendidikan Bahasa Arab 8, no. 1 (2017): 77.

${ }^{9}$ Diane Larsen-Freeman, Techniques and Principles in Language Teaching, 2nd ed., [Nachdr.], Teaching Techniques in English as a Second Language (Oxford: Oxford Univ. Press, 2008), 45. 91 | Jurnal Al Bayan: Jurnal Jurusan Pendidikan Bahasa Arab, 13 (1): 90-107 (2021)
} 
implementation of the methods, especially eclectic method and their connection with Arabic language skills. With further explanation, eclectic methods hopefully can be used dynamically in Arabic learning activity. As the teachers, they must understand the method. Besides, the students' understanding during the learning process is very substantial towards the quality of the planned learning. This article explains about the implementation of eclectic method based on All in One system approach at learning Arabic language.

\section{Method}

This research is a library research. The collecting data is based on reading some literature that can provide information and have relevance to the research topic. In this study, researchers used data collection techniques by exploring and searching from sources of books, journal articles, or matters relating to the topic of this study. The authors took primary data from previous research related to the implementation of eclectic methods in learning Arabic. In this study the authors will analyze the implementation of an eclectic method based on an all in one system approach. After the required data is collected, the researcher then analyzes the data with descriptive data analysis techniques and data interpretation. Afterwards, the researcher gives sufficient explanation.

\section{Result and Discussion}

Eclectic method is considered to be the suitable method for teaching in the $21 \mathrm{st}$ Century. The characteristics of this method are suitable for teaching four language skills. Eclectic method is a comprehensive method. This method combines the advantages of a variety of different methods. These methods are systematically and logically combined to meet the diverse needs of learners. ${ }^{10}$ Yusuf and Wekke (2018) explained that the application of the eclectic method was based on several considerations. First, the purpose of learning. The teacher must determine the suitable method for achieving the learning objectives. Second, the different academic, social, and student characteristics in learning affect the chosen method. Third, the condition of learning facilities such as buildings and classrooms that support during the learning process.

${ }^{10} \mathrm{D}$ Larsen-Freeman, Techniques and principles in language teaching (Oxford: Oxford University Press, 2004), 60. 
This method is used because it is proven effective without making students feel overwhelmed $^{11}$. Arabic language teaching might be ineffective if only one particular method is used. A method that is able to integrate several methods and techniques into language teaching is needed. Based on previous research, eclectic method is an effective method in teaching second languages. According to Najebullah (2018) ${ }^{12}$, eclectic method combines several methods in language teaching and produces flexible and enjoyable English language teaching. Chinta Praveen Kumar proved that the diversity of methods, frequent interactions with students, suitable learning activity in learners' daily life, and improved learning outcomes are considered as the advantages of eclectic method. ${ }^{13}$ Eclectic approach is popular because of its effectiveness in producing good results without putting much pressure on the learners. Hence, the learners are given the objective of learning so that they are able to produce the best results as soon as possible.

The important features of this approach includes, multiple tasks, high interaction among teachers and students, lively learning. ${ }^{14}$ Quisher and Ishtiaq cited the results of Siddiqui which compared direct methods, communicative methods ESL teaching and concluded that eclectic method is effective method based on condition of the students ${ }^{15}$. Sagar and Afzal concluded that the use of eclectic methods can keep students away from boredom, the class becomes more attractive, increasing students' communication skills so that learning objectives can be achieved ${ }^{16}$. Some of the discussions above explained the benefits of eclectic methods and their application in English subjects.

Characteristics of Arabic learning in Madrasah (Islamic school) in 2019 emphasize that Arabic learning today is not only centered on conventional learning systems which only learn about its grammatical structures, but more focus on its function or applicative abilities. It is also mentioned that Arabic learning is oriented to improve

${ }^{11}$ Muhammad Yusuf dan Ismail Suardi Wekke, "Teaching and Learning Arabic and Quran through Ecletic Method in Islamic School," International Journal of Pure and Applied Mathematics, 18, 119 (2018): 15.

${ }^{12}$ Najeebullah, Rabia Tabassum, dan Irfanullah, "Effect of the Eclectic Approach of Teaching on English Communication Skills at Elementary Level," Modern Journal of Language Teaching Methods 8, no. 6 (2018): 76.

${ }^{13}$ Chinta Praveen Kumar, "The Eclectic Method- Theory and Its Application to the Learning of English" 3, no. 6 (2013): 4.

${ }^{14}$ Larsen-Freeman, Techniques and principles in language teaching, 86.

15 Qaiser Suleman dan Ishtiaq Hussain, "Effects of Eclectic Learning Approach on Students' Academic Achievement and Retention in English at Elementary Level," Journal of Education and Practice, (2016): 6.

${ }^{16}$ N Sagar dan Thahiya Afzal, "English Language Teaching Through Eclectic Approach for Engineering Students" 7, no. 5 (2019): 4. 
language skills (al-Maharah al-Lughawiyah) ${ }^{17}$. Besides, the development of Arabic language curriculum in Madrasah still tends to be structural, less functional and less communicative. The need for the development of an Arabic curriculum does not only focus on the Arabic grammar, but also on Arabic language skills such as listening, speaking reading, and writing ${ }^{18}$. The learning objectives listed in KMA 183 are in accordance with the principles listed in the integrative approach. This approach refers to the function or nature of language for human being. (Freeman 1992) said that the different components of language (pronunciation, grammar, vocabulary, etc.) have no meaning when these components are separated. Language should not be separated such as pronunciation, grammar, and vocabulary ${ }^{19}$.

With an emphasis on teaching Arabic skills as a second language aims to: (1) practice the ability of students to understand Arabic while listening. (2) train students' ability so that they can pronounce Arabic correctly and can communicate well with native speaker. (3) train students' ability to read Arabic writing accompanied by clear understanding and be able to write carefully and correctly according to Arabic grammar. All in One System approach is an approach which convinced that nature of language is a unity and not the separate elements ${ }^{20}$. So, All in One System approach is defined as an approach that views the teaching of the four language skills (listening skills, speaking skills, writing skills, reading skills) and language elements (language sounds, vocabulary and written conventions in an integrated manner. This approach is known in Arabic as Nazhariyyah al-Wihdah theory ${ }^{21}$.

All elements and language skills in this approach are interrelated so that they are considered the closest to the nature of language. In the research of Abul Alim (1961), an approach that is integrative or not separate is more appropriate if used to be a method in language teaching for beginner and intermediate level students, because beginner and intermediate level students require all aspects of language skills to be taught simultaneously ${ }^{22}$. In addition, the use of the all in one system approach is also based on

17 “KMA No 183 Tahun 2019 Tentang Kurikulum PAI dan Bahasa Arab pada Madrasah, 9.

18 "KMA No 183 Tahun 2019 Tentang Kurikulum PAI dan Bahasa Arab pada Madrasah, 9.

${ }^{19}$ Kumar, "The Eclectic Method- Theory and Its Application to the Learning of English.", 98.

${ }^{20}$ Chatibul Umam, et al, Pedoman Pengajaran Bahasa Arab Pada Perguruan Tinggi Agama (Jakarta: Proyek Pengembangan Sistem Pendidikan Agama Departemen Agama RI, 1957), 173.

${ }^{21}$ Jabl Nur, "Konsep Nazhariyah al-Wihdah Dalam Pembelajaran Bahasa Arab," Jurnal al-Ta'dib, 1, 8 (2016): 5 .

22 'Abd al-'Alīm Ibrāhīm, al-Muwajjih al-fannī li-mudarrisī al-lughah al- 'Arabīyah, (1961), 207. 
psychological and linguistic principles. Psychologically, diverse nuances and learning activities can arouse students' motivation to learn and prevent them from boredom.

\section{Language Principles of Language Learning with All in One System Approach}

To achieve learning objectives, teachers need to concern on the principles of learning for the achievement of objectives in learning ${ }^{23}$. All in One system is an alternative approach in teaching language which has the following principles:

\section{Psychological Principles}

The definition of All in One system approach is in accordance with the psychological principles of students. Students at beginner and intermediate levels need teaching methods that are not boring. In this approach there is a diversity of language skills so that students are not bored and enthusiastic in learning languages ${ }^{24}$. Certainly, it is different to teach foreign languages with mother tongue so that mastery of psychological principles by the teacher is able to create a more meaningful learning process. Thus, the teacher can know how they should teach language to students properly ${ }^{25}$.

Knowledge of these psychological principles will greatly help teachers to find effective teaching methods or technique in teaching four aspects of skills (reading, writing, speaking, listening) and language elements (pronunciation, vocabulary, rules). In teaching with this approach, instructors are required to frequently repeat in exercises. In one topic of teaching material, the subject must include integrated four language skills. This repetition process makes the material more easily understood by students. If the teacher gives material, the principle must be integrated in the four Arabic language skills including istima ', qiraah, muhadatsah and kitabah ${ }^{26}$.

\section{Linguistic Principles}

William G Moulton explained that the need to teach language in accordance with the principles of language or linguistics. First, language is speaking activity, not writing. So, teaching activity should start from listening and speaking, the next step is reading and writing. Second, language teaching activity is about how language can be implemented,

${ }^{23}$ Tayyar Yusuf dan Saiful Anwar, Metodologi Pengajaran Agama dan Bahasa Arab (Jakarta: Raja Grafindo Persada, 1995), 125.

${ }^{24}$ Muhammad Rusydi Rasyid, “All In One System (Pendekatan Dan Prinsip Psikologis Pengajaran Bahasa Arab Terintegrasi)," Lentera Pendidikan : Jurnal Ilmu Tarbiyah dan Keguruan 12, no. 1 (29 Juni 2009): 33-45.

${ }^{25}$ Wright T, Rules of Teachers and Learners (oxford: Oxford University Press, 1987), 43. 
not only about the language itself ${ }^{27}$. Third, competence or language skills are obtained from the language learning environment. This habituation begins by imitating and remembering. By understanding deeply the scope of linguistics, students and teachers can choose learning materials or teaching materials systematically (Kridalaksana, 2005). Linguistic principles can be taught through various methods and approaches.

All in One System Principle is in line with the linguistic principle which holds that language learning activities start from listening, speaking, reading and then writing ${ }^{28}$. This is in accordance with the principle of language, namely language is speech. The use of language in the classroom by the teacher in the classroom is also important because in the classroom the teacher is a role model for students. With the habit of speaking in that language, students' ability to communicate can be developed. However, there are still many Arabic language teachers who actually use their first language in the classroom.

\section{Eclectic Method}

The development of the eclectic method began in the early 1990s and became popular lately ${ }^{29}$. Sanjaya in his book on Learning Strategies conveyed his definition of methods. According to him, the method is an effort to implement a learning plan or strategy to maximize learning objectives used to carry out a job in order to achieve something desired ${ }^{30}$. Based on Indonesian dictionary, the Indonesian Language Editor's Team, method is a systematic way of working to facilitate the implementation of an activity in order to achieve the specified goals or an orderly method used to carry out a job in order to achieve something desired ${ }^{31}$.

Eclectic method existed because each method has its own advantage and the method that concerned on learning conditions had not been found yet. Brown (2002) argued that the dynamic classroom eclecticism might provide the solution, because this approach allows the teacher to choose what methods are appropriate to realize the

\footnotetext{
${ }^{26}$ Rusydi Rasyid, "All In One System (Pendekatan Dan Prinsip Psikologis Pengajaran Bahasa Arab Terintegrasi)," Lentera Pendidikan : Jurnal Ilmu Tarbiyah dan Keguruan 12, no. 1 (29 Juni 2009): 34.

${ }_{27}$ Jos Daniel Parera, Linguistik Edukasional: Pendekatan, Konsep, dan Teori Pengajaran Bahasa (Jakarta: Penerbit Erlangga, 1986), 31.

${ }_{28}$ Rusydi Rasyid, "All In One System (Pendekatan Dan Prinsip Psikologis Pengajaran Bahasa Arab Terintegrasi)," Lentera Pendidikan : Jurnal Ilmu Tarbiyah dan Keguruan 12, no. 1 (29 Juni 2009): 36.

${ }^{29}$ Kumar, "The Eclectic Method- Theory and Its Application to the Learning of English," 65.

30 Wina Sanjaya, Strategi Pembelajaran Berorientasi Standar Proses Pendidikan, (Jakarta: Kencana, 2016), 126.

31 Tim Redaksi Kamus Besar Bahasa Indonesia, "Kamus Besar Bahasa Indonesia" (Jakarta: Depdiknas, 2008), 956.
} 
dynamic classroom conditions ${ }^{32}$. Gilliland, James and Bowman stated that the classical method become an alternative method based on the view that the weaknesses of a single method. ${ }^{33}$ Eclectic means choosing from various sources. Eclectic is the method which chooses excellence from various methods of language teaching available. There are other names of the eclectic method as follows:

الطريقة الانتقائية, الطريقة المختارة, الطريقة التوفيقية,الطريقة المزدوجة34

The definition of other eclectic methods is:

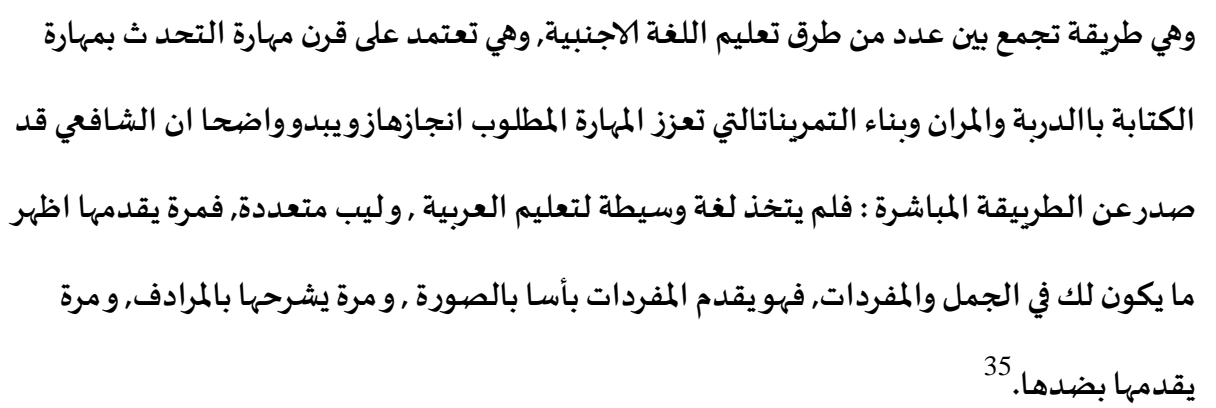

According to Ahmad Izzan, intiqaiyyah method is the use of various methods as a tool to achieve learning objectives. Hence, several methods are used at once in a topic or theme in language learning. ${ }^{36}$

\section{Basic Concepts of Eclectic Method}

Eclectic method is an alternative method in language learning by taking advantage of various methods. This method also has a basic concept that is used as a reference. The basic concept: First, the basic assumption is that each method has different characteristics. The advantages of the method are then used by the instructor to teach appropriate language skills. Second, each method has a concept, characteristics and background. If these advantages are put together then collaboration will occur in achieving successful learning. Third, every teacher in teaching in the classroom is free to

\footnotetext{
32 David Sani Mwanza, "The Eclectic Approach to Language Teaching: Its Conceptialisation and Misconceptions," International Journal of Humanities, Social Sciences and Education 4, no. 2 (2017): 52.

${ }^{33}$ Mwanza, 52.

${ }^{34}$ Ahmad Fuad Efendi, Metodologi Pengajaran Bahsa Arab (Malang: Misykat, 2009), 71.

${ }^{35}$ Anati Walid, "Nun wa al-Qalam" Dirasah Lisaniyah Tarbawiyah li Ta'lim al-Arabiyyah li alNathiqin bi Ghairiha (Yordania: Jamiah al-Batra, 2009), 45.

36 Ahmad Izzan, Metodologi Pembelajaran Bahasa Arab (Bandung: Metodologi Pembelajaran Bahasa Arab, 2009), 111.
} 
determine the steps, techniques, and methods of teaching by looking at the needs of students ${ }^{37}$.

Because this eclectic approach is based on the perceptions of each teacher in accordance with the context of learning and teaching, it can be said that the eclectic approach is a subjective approach. This approach depends on the method chosen by the teacher based on factors influencing the class. The teacher is free to choose what method is appropriate for them and decides to integrate the method in learning ${ }^{38}$. Each teacher may have different perceptions related to the application of an eclectic method, but all of them still refer to the aims and basis of teaching with an eclectic method is that students can access learning without feeling difficult.

\section{Advantages and Disadvantages from Eclectic Method}

As a language learning method, the eclectic method has several advantages and disadvantages. The eclectic method adopts the advantages of other methods as well as the answer to the weaknesses of the previous methods. The advantages of the eclectic method are as follows: First, A subjective approach to teaching. In most cases the construction of the eclectic approach for a particular class or lesson is built by the teachers, according to their students need and abilities. A particular teacher decides the choice of methods or combination of different methods into their teaching ${ }^{39}$. Second, Situational or specific context. Hence, according to the context of teaching and learning, the understanding and the implementation of the approach should be contextualizes or in simple words, it should be localized. Kumaradivadelu stated that global principles (are) for general guidance, but their implications need to be worked out for local everyday practice $^{40}$.

Third, eclectic method provides correction of the mistake at the end of every communicative activity. The teachers and the fellow students involve in correcting the mistake of the other students will help them to learn from mistakes ${ }^{41}$. Fourth, different methods are borrowed and adapted to suit the requirement of the learners at different conditions. Practicing an eclectic approach helps to overcome boring classroom activity.

\footnotetext{
${ }^{37}$ Muhammad 'Ali Al-Khouli, Asalibu Tadrisi Al-Lughotil 'Arobiyyah (Riyadl: Darul Ulum, 1989), $25-26$.

${ }^{38}$ Mwanza, "The Eclectic Approach to Language Teaching," 57.

${ }^{39}$ M.D Makmun dan Jakir, "Advocacy of The Eclectic Approach to ESL dan EFL Teaching in Bangladesh," Jagannath University Journal of Arts, (2020): 128.

40 B Kumaravadivelu, "Understanding Language Teaching :From Method to Post Method," International Journal of Humanities, Social Sciences and Education, (2006): 124.
} 
To make it effective, a teacher must have a good understanding of students' experiences, their goals and language style, etc. Teachers are also free to choose their own strategies according to student learning conditions. Fifth, every aspect of language skills is covered. The eclectic approach is broad and may cover almost all types learning activities. It blends the practice of four macro-listening skills, speaking, reading, and writing. In fact, students have a need to learn a wide variety of skills, and a different approach is useful to teach various aspects of language skills. It is clear that anyone methods do not serve the true purpose of teaching all languages Skills.

Therefore, teaching Arabic with a combination of various methods and approaches will help teachers to teach Arabic effectively. The eclectic method is in accordance with all in one system approach that concerns on psychological and linguistic aspects. Disadvantage of the eclectic method are described as follows: Not all teacher or instructor has the ability to flexibly use direct method and grammar-translation. There is an imbalance between the complex and extensive material with the time available. It might take adequate facilities and infrastructure to maximize teaching and learning process with an eclectic method with so many competencies to be mastered, opportunities for reading, speaking and composing practice. Mahmud Yunus said that according to this theory, there is an opportunity for practicing reading, speaking and writing, but at the end, all language lessons objective is that students can read, speak and write in Arabic ${ }^{42}$. At the application stage, the eclectic method must be applied by the professional instructor and have skills that every educational institution might not have ${ }^{43}$. This method also requires a teacher to have good time management, so that the material can be understood completely.

The advantages and disadvantages of this method can be known after implementation of this method is done, because there is no measurement that this method has advantages and disadvantages. This method can be an ideal alternative method if the teacher uses this method well and can adapt to the needs of the program the teaching.

\footnotetext{
${ }^{41}$ Mwanza, "The Eclectic Approach to Language Teaching," 46.

${ }^{42}$ Rahman, "Pengajaran Bahasa Arab Dengan Metode Eklektik," 73.

${ }^{43}$ Ikhwan Nur Rois dan Riska Izani, "Implementasi Ath-Thariqah Al-Intiqaiyyah Dalam Memahami Kaidah Bahasa Arab Bagi Pemula,” (2019): 17.
} 


\section{Implementation of the Eclectic Method in Arabic learning with All in One System} Approach

Various methods have been developed related to language learning and each method has different characteristics and also different class segments ${ }^{44}$, for example, Grammatical Translation Method which focuses on grammar skills but ignores students' communication skills. Meanwhile, communicative methods that focuses on the ability to speak ignores the students' grammar abilities ${ }^{45}$, for this reason, an approach that supports students to have receptive and productive abilities is needed in the sense that students are able to master four language skills as well.

Basically Arabic teaching in formal schools experiences differences due to several factors that influence. The distinguishing factors are the availability of media and infrastructure, the ability of teachers, the condition of students and also the learning objectives to be achieved ${ }^{46}$. The emergence of this method is caused by the various factors. Language instructors can use eclectic method to make language teaching effective in the classroom. The instructor also teaches four language skills to determine the variety of methods they use.

From the explanation above, to achieve the learning objective, which is four language skills mastery, the principle of All in One System approach is used which holds that the ability of students in reading, writing, listening and speaking Arabic is considered as a complementary whole without being separated. The importance of applying All in One System approach is to determine the appropriate method to support the approach. The approach is only a set of assumptions. These assumptions require a method for making systematic language teaching designs using All in One System approach $^{47}$. Based on the assumptions in All in One System approach, eclectic method was used which is considered to be suitable for the approach.

\section{Goals and Learning Process with the Eclectic Method}

Wali in his research concluded that one of the goals of the eclectic method is for the teacher to focus on teaching and not focus on the learning method. Thus, the teacher

${ }^{44}$ R. Umi Baroroh dan Abdul Kahfi Amrullah, "Hypnoteaching Method in Arabic Learning," Jurnal Al Bayan: Jurnal Jurusan Pendidikan Bahasa Arab, (2019): 133-48.

${ }^{45}$ Najeebullah, Rabia Tabassum, dan Irfanullah, "Effect of the Eclectic Approach of Teaching on English Communication Skills at Elementary Level," 33.

46 fitri Alrasi, "Penggunaan Metode Eklektik ( Thariqah Intiqoiyyah) Terhadap Pembelajaran Bahasa Arab Di Akper Aisyiyah Padang” 1, no. 1 (2018): 12.

${ }^{47}$ Efendi, Metodologi Pengajaran Bahsa Arab, 85. 
is free to choose suitable techniques and procedures in the classroom. Every method in language learning has different characteristic, advantages and disadvantages. With the variation in eclectic methods, the teacher is expected to be able to have a strategy that suits students' needs. The teacher can use the flexible method choices for achieving language learning targets ${ }^{48}$.

Arabic Learning in non-Arabic countries requires a variety of creativity in teaching languages because Arabic is considered as high level language of its difficulty. In one study, it was found that students in Cebuano were stressed and overwhelmed in Arabic classes. Hence, a solution is needed so that the teacher is able to handle it well ${ }^{49}$. The use of eclectic method is expected to make students not feel bored in learning. Teachers can combine the methods that are suitable with learning objectives such as Grammar-Translation method, Direct Method, and Audiolingual method ${ }^{50}$. Zarkani stated that this method is the ideal method because of its various advantages ${ }^{51}$. Mahmud Kamil Al-Naqoh described in his book that the purpose of learning Arabic for students with an eclectic method is to understand the spoken language, to practice speaking skills, to practice reading skills and to improve the ability to write ${ }^{52}$.

The first goal in this method is that students are able to understand language with listening skills. Teachers can use the Shamiyah Shawiyah method which supports the achievement of learning objectives. At this stage, the Arabic language material is taught by training students to function optimally in their sense of hearing. The second goal is to train students to be able to speak us. Teachers can start by giving examples of pronunciation then followed by students. At this stage, students are invited to imitate the sentence that is spoken by the teacher. The third goal of this method is that students are able to use the sense of sight in reading Arabic material/writing. The teacher invites students to read what was said in the previous stage. The fourth goal of the eclectic method is that students learn to use the skills to arrange words, grammar, sentence patterns in written form.

\footnotetext{
${ }^{48}$ Nizar Husein Wali, "Eclecticism and Language Learning," Al- Fatih Journal Diyala University College of Basic Education, (2009): 40.

49 Anas Huneety dkk., "Stress Production by Cebuano Learners of Arabic: A Metrical Analysis," Indonesian Journal of Applied Linguistics 9, no. 3 (10 Februari 2020): 517-25.

50 Alrasi, "Penggunaan Metode Eklektik (Thariqah Intiqoiyyah) terhadap Pembelajaran Bahasa Arab Di Akper Aisyiyah Padang," 96.

${ }^{51}$ Mohammad Zarkani, "Efektivitas Metode Eklektik Dalam Pembelajaran Bahasa Arab" 4 (2019): 42.
} 
The steps of teaching and learning activities by using the eclectic method are as follows $^{53}$ : Introduction, by preparing students psychologically and physically. The teacher can also repeat the past material to test students' attention to the material. The teacher gives material in the form of short dialogues or new vocabulary delivered verbally. It can be done using gestures, pictures or visual and audiovisual media as well. So, the students are able to use the listening skill to identify or recognize foreign sentences. After knowing and listening to the vocabulary in dialogue, students are directed to repeat. It is expected that students will know the big theme of the text. Then, it is repeated together. Students are expected to be fluent in reading after repeating the dialogue with the direction of the teacher. If students have difficulty in understanding vocabulary, the teacher will give signals through body movements, pictures and other media prepared by the teacher. If students do not understand, it will be translated in the student's native language. The learning material is repeated in written form. The teacher provides understanding of writing correctly to students through the media available in class. Can use a projector or directly on the board. The teacher repeats the sentence verbally and gives a few questions which starts from the easiest. The purpose of this stage is to know the level of understanding of students in learning. If there is still time left, the teacher can provide some homework for students. ${ }^{54}$

Learning materials that attract and motivate students are important in the application of eclectic methods. The urgency in choosing teaching materials is based on the needs and academic abilities of these students. Weidemann asserted that effective language teachers allocate a lot of time to gather interesting teaching and learning materials for the achievement of learning objectives. In teaching with an eclectic method teachers can use teaching materials such as textbooks, chats, magazines, newspapers, radio, films, music, maps, pictures and computers. The teacher can use visual or linguistic media ${ }^{55}$. Teachers who use eclectic methods must be creative and can use learning materials and media well in accordance with the learning theme.

\footnotetext{
${ }^{52}$ Ikhwan Nur Rois dan Riska Izani, "Implementasi Ath-Thariqah Al-Intiqaiyyah Dalam Memahami Kaidah Bahasa Arab Bagi Pemula," (2019): 92.

${ }^{53}$ Acep Hermawan, Metodologi Pembelajaran Bahasa Arab (Bandung: Remaja Rosdakarya, 2011), 39.

${ }^{54}$ Hermawan, 143.

55 A Weidemann, "The Old and the New: Reconsidering Eclecticism in Language Teaching," Linguam, 17(1):1-13.
} 


\section{Factors That Influence Learning Success with the Eclectic Method}

First point is the creativity of the teacher in managing learning in the classroom. Dornyei in her research said that the classroom situation was one of the main factors in increasing students' interest in learning in class. Teachers are required to be able to control the classroom situation. To make the learning experience interesting, instructors are asked to continually update their teaching methodology to accommodate the increased interest of students in language learning ${ }^{56}$. Second, the teacher has a growth mindset about pedagogy. A good teacher with a growth mindset does not only concern on the strategies and methods in learning, but also supports students' processes. The teacher also helps students to identify the difficulties and find a solution together. A good teacher has to know how to support the students and provide something they need $^{57}$.

Third, the material or learning strategies are modified. In teaching language skills with eclectic method, teachers can also modify learning materials with teacher creativity so that students are more motivated to learn and develop their language competencies. To increase learning interest and support understanding, teachers can teach something that still related to the student's environment (contextual learning) ${ }^{58}$. This is supported by Noza Afilisia which shows that Arabic teaching materials can be integrated with local wisdom. Through learning Arabic based on local wisdom, students are expected to not only be experts in Arabic but also be able to appreciate and preserve the natural culture around them ${ }^{59}$. Fourth, good relations between students and teachers are important in increasing students' interest and motivation as well as influencing their achievement. For example, when a teacher always praises students, it will encourage students to actively participate in learning. The active involvement of students implies the teacher has a positive relationship with students ${ }^{60}$.

\footnotetext{
${ }^{56}$ Ahmad Bukhori Muslim, Fuad Abdul Hamied, dan Didi Sukyadi, "Integrative and Instrumental but Low Investment: The English Learning Motivation of Indonesian Senior High School Students," Indonesian Journal of Applied Linguistics 9, no. 3 (10 Februari 2020): 493-507.

${ }^{57}$ Inkeri Rissanen dkk., "In Search of a Growth Mindset Pedagogy: A Case Study of One Teacher's Classroom Practices in a Finnish Elementary School," Teaching and Teacher Education 77 (Januari 2019): 405.

${ }^{58}$ Muslim, Hamied, dan Sukyadi, "Integrative and Instrumental but Low Investment," 510.

${ }^{59}$ Noza Aflisia dan Ahmad Fikri, "Integration of Local Wisdom in Arabic Learning," Jurnal Al Bayan: Jurnal Jurusan Pendidikan Bahasa Arab, (2019): 356-73.

${ }^{60}$ Helena J.M. Pennings dkk., "Real-Time Teacher-Student Interactions: A Dynamic Systems Approach,” Teaching and Teacher Education 37 (Januari 2014): 183-193.
} 


\section{Conclusion}

Finally, the result of this research showed that implementation of eclectic method based on all in one system approach is effective for learning Arabic language because it is in accordance with linguistic principles and psychological principles. For this approach to be effective, a teacher must have a good understanding of students' experiences, their goals and language style. Teachers who use eclectic methods must be creative and can use learning materials and media in accordance with the learning theme. In the future, further studies are needed, such as Arabic learning handbook for eclectic methods, and a combination of Arabic teaching methods that are suitable with eclectic methods.

\section{Acknowledgment}

The authors would like to express gratitude to UIN Sunan Kalijaga especially Arabic Education Magister Program for supporting this research. This research could be done because the supportive atmosphere of academic and the support from the academy, lecturers, and students in learning and teaching process

\section{References}

Aflisia, Noza, dan Ahmad Fikri. "Integration of Local Wisdom in Arabic Learning." Jurnal Al Bayan: Jurnal Jurusan Pendidikan Bahasa Arab, 2019, 356-73.

'Ali Al-Khouli, Muhammad. Asalibu Tadrisi Al-Lughotil 'Arobiyyah. Riyadl: Darul Ulum, 1989.

Alrasi, Fitri. "Penggunaan Metode Eklektik (Thariqah Intiqoiyyah) Terhadap Pembelajaran Bahasa Arab di Akper Aisyiyah Padang” 1, no. 1 (2018): 10.

Baroroh, R. Umi, dan Abdul Kahfi Amrullah. "Hypnoteaching Method in Arabic Learning." Jurnal Al Bayan: Jurnal Jurusan Pendidikan Bahasa Arab, 2019, 13348.

Brown, H.D. Principles of language learning and teaching. New York: Longman, 2000.

Efendi, Ahmad Fuad. Metodologi Pengajaran Bahsa Arab. Malang: Misykat, 2009.

Fahrurrozi, Aziz. "Pembelajaran Bahasa Arab: Problematika Dan Solusinya." ARABIYAT: Jurnal Pendidikan Bahasa Arab dan Kebahasaaraban 1, no. 2 (28 Desember 2014): 161-80.

Hermawan, Acep. Metodologi Pembelajaran Bahasa Arab. Bandung: Remaja Rosdakarya, 2011. 
Hijriyah, Umi Hijriyah. "Pendekatan-Pendekatan Dalam Belajar Bahasa." Jurnal Al Bayan: Jurnal Jurusan Pendidikan Bahasa Arab 8, no. 1 (2017).

Huneety, Anas, Bassil Al Mashaqba, Majed Al-Quran, dan Jehan Hishma Mail. "Stress Production by Cebuano Learners of Arabic: A Metrical Analysis." Indonesian Journal of Applied Linguistics 9, no. 3 (10 Februari 2020): 517-25.

Ibrāhīm, 'Abd al-'Alīm. al-Muwajjih al-fannī li-mudarrisī al-lughah al-'Arabīyah., 1961.

'Iwadh, Ahmad Abu. Pendekatan Pendekatan dalam Pembelajaran Bahasa Arab. Makkah al Mukarramah, 2000.

Izzan, Ahmad. Metodologi Pembelajaran Bahasa Arab. Bandung: Humaniora, 2004. . Metodologi Pembelajaran Bahasa Arab. Bandung: Metodologi Pembelajaran Bahasa Arab, 2009.

“KMA No 183 Tahun 2019 Tentang Kurikulum PAI dan.pdf,” t.t.

Kumar, Chinta Praveen. "The Eclectic Method- Theory and Its Application to the Learning of English" 3, no. 6 (2013): 4.

Kumaravadivelu, B. "Understanding Language Teaching :From Method to Post Method." International Journal of Humanities, Social Sciences and Education, 2006.

Larsen-Freeman, D. Techniques and principles in language teaching. Oxford: Oxford University Press, 2004.

Larsen-Freeman, Diane. Techniques and Principles in Language Teaching. 2nd ed., [Nachdr.]. Teaching Techniques in English as a Second Language. Oxford: Oxford Univ. Press, 2008.

Makmun, M.D, dan Jakir. "Advocacy of The Eclectic Approach to ESL dan EFL Teaching in Bangladesh.” Jagannath University Journal of Arts, t.t., 2020.

Makruf, Imam. "Manajemen Integrasi Pembelajaran Bahasa Arab di Madrasah Berbasis Pondok Pesantren." Cendekia: Journal of Education and Society 14, no. 2 (13 Desember 2016): 265

Muslim, Ahmad Bukhori, Fuad Abdul Hamied, dan Didi Sukyadi. "Integrative and Instrumental but Low Investment: The English Learning Motivation of Indonesian Senior High School Students.” Indonesian Journal of Applied Linguistics 9, no. 3 (10 Februari 2020): 493-507.

Mwanza, David Sani. "The Eclectic Approach to Language Teaching: Its Conceptialisation and Misconceptions." International Journal of Humanities, Social Sciences and Education 4, no. 2 (2017)..

Najeebullah, Rabia Tabassum, dan Irfanullah. "Effect of the Eclectic Approach of Teaching on English Communication Skills at Elementary Level." Modern Journal of Language Teaching Methods 8, no. 6 (2018). 
Nur, Jabl. "Konsep Nazhariyah al-Wihdah Dalam Pembelajaran Bahasa Arab.” Jurnal alTa'dib, 1, 8 (2016).

Parera, Jos Daniel. Linguistik Edukasional: Pendekatan, Konsep, dan Teori Pengajaran Bahasa. Jakarta: Penerbit Erlangga, 1986.

Pennings, Helena J.M., Jan van Tartwijk, Theo Wubbels, Luce C.A. Claessens, Anna C. van der Want, dan Mieke Brekelmans. "Real-Time Teacher-Student Interactions: A Dynamic Systems Approach." Teaching and Teacher Education 37 (Januari 2014): 183-93. Rahman, Anwar Abd. "Pengajaran Bahasa Arab Dengan Metode Eklektik.” Jurnal Adabiyah 11 (2011): 10.

Rissanen, Inkeri, Elina Kuusisto, Moona Tuominen, dan Kirsi Tirri. "In Search of a Growth Mindset Pedagogy: A Case Study of One Teacher's Classroom Practices in a Finnish Elementary School." Teaching and Teacher Education 77 (Januari 2019): 204-13.

Rois, Ikhwan Nur, dan Riska Izani. "Implementasi Ath-Thariqah Al-Intiqaiyyah Dalam Memahami Kaidah Bahasa Arab Bagi Pemula,” 2019, 17.

. "Implementasi Ath-Thariqah Al-Intiqaiyyah Dalam Memahami Kaidah Bahasa Arab Bagi Pemula," 2019, 17.

Roviin. "Pengembangan Kurikulum Bahasa Arab di Madrasah (Analisis Pendekatan, Model dan Prosedur).” Jurnal Tarling, 1, 2 (2018).

Sagar, N, dan Thahiya Afzal. "English Language Teaching Through Eclectic Approach for Engineering Students" 7, no. 5 (2019): 4.

Sanjaya, wina. Strategi Pembelajaran Berorientasi Standar Proses Pendidikan,. Jakarta: Kencana, 2016.

Suleman, Qaiser, dan Ishtiaq Hussain. "Effects of Eclectic Learning Approach on Students' Academic Achievement and Retention in English at Elementary Level." Journal of Education and Practice, 2016, 6.

Tim Redaksi Kamus Besar Bahasa Indonesia. “Kamus Besar Bahasa Indonesia.” Jakarta: Depdiknas, 2008.

Umam, et al, Chatibul. Pedoman Pengajaran Bahasa Arab Pada Perguruan Tinggi Agama. Jakarta: Proyek Pengembangan Sistem Pendidikan Agama Departemen Agama RI, 1957.

Universitas Islam Negeri Alauddin Makassar, dan Muhammad Rusydi Rasyid. "All In One System (Pendekatan Dan Prinsip Psikologis Pengajaran Bahasa Arab Terintegrasi)." Lentera Pendidikan : Jurnal Ilmu Tarbiyah dan Keguruan 12, no. 1 (29 Juni 2009): 33-45.

Wali, Nizar Husein. "Eclecticism and Language Learning." Al- Fatih Journal Diyala University College of Basic Education, 2009. 
Walid, Anati. "Nun wa al-Qalam" Dirasah Lisaniyah Tarbawiyah li Ta'lim alArabiyyah li al-Nathiqin bi Ghairiha. Yordania: Jamiah al-Batra, 2009.

Weidemann, A. "The Old and the New: Reconsidering Eclecticism in Language Teaching." Linguam, 17(1):1-13, t.t..

Wright T. Rules of Teachers and Learners. oxford: Oxford University Press, 1987.

Yusuf, Muhammad, dan Ismail Suardi Wekke. "Teaching and Learning Arabic and Quran through Ecletic Method in Islamic School." International Journal of Pure and Applied Mathematics, 18, 119 (2018): 15.

Yusuf, Tayyar, dan Saiful Anwar. Metodologi Pengajaran Agama dan Bahasa Arab. Jakarta: Raja Grafindo Persada, 1995.

Zarkani, Mohammad. "Efektivitas Metode Eklektik Dalam Pembelajaran Bahasa Arab" 4 (2019): 16. 